\title{
Resistance mechanisms to drug therapy in breast cancer and other solid tumors: An opinion [version 1; peer review: 2
}

\section{approved, 1 approved with reservations]}

\section{Fedor V. Moiseenko1,2, Nikita Volkov², Alexey Bogdanov(D1-4, Michael Dubina1-3, Vladimir Moiseyenko²}

\author{
${ }^{1}$ St Petersburg Academic University, St. Petersburg, 194021, Russian Federation \\ ${ }^{2}$ St. Petersburg Clinical Research and Practical Center for Specialized Types of Medical Care (Oncologic), St. Petersburg, 197758, \\ Russian Federation \\ ${ }^{3}$ Peter the Great St. Petersburg Polytechnic University, St. Petersburg, 195251, Russian Federation \\ ${ }^{4}$ The Petersburg Nuclear Physics Institute, Gatchina, 88300, Russian Federation
}

V1 First published: 17 Mar 2017, 6:288

https://doi.org/10.12688/f1000research.10992.1

Latest published: 17 Mar 2017, 6:288

https://doi.org/10.12688/f1000research.10992.1

\section{Abstract}

Cancer is an important contributor to mortality worldwide. Breast cancer is the most common solid tumor in women. Despite numerous drug combinations and regimens, all patients with advanced breast cancer, similarly to other solid tumors, inevitably develop resistance to treatment. Identified mechanisms of resistance could be classified into intra- and extracellular mechanisms. Intracellular mechanisms include drug metabolism and efflux, target modulations and damage restoration. Extracellular mechanisms might be attributed to the crosstalk between tumor cells and environmental factors. However, current knowledge concerning resistance mechanisms cannot completely explain the phenomenon of multi-drug resistance, which occurs in the vast majority of patients treated with chemotherapy. In this opinion article, we investigate the role of these factors in the development of drug-resistance.

\section{Keywords}

cancer, breast cancer, chemotherapy, resistance

\section{Open Peer Review \\ Approval Status ? \\ 12 \\ 23 \\ version 1 \\ 17 Mar 2017

$?$
view \\ view}

1. Alexey Tryakin, N.N. Blokhin Russian Cancer Research Center, Moscow, Russian

Federation

2. Phei Er Saw iD, Harvard Medical School, Boston, USA

3. Anna Herman-Antosiewicz, University of Gdańsk, Gdańsk, Poland

Any reports and responses or comments on the article can be found at the end of the article. 
Corresponding authors: Fedor V. Moiseenko (moiseenkofv@gmail.com), Nikita Volkov (volkovnm@gmail.com), Alexey Bogdanov ( aleks_aa@mail.ru)

Competing interests: No competing interests were disclosed.

Grant information: This work was supported by The Ministry of Education and Science of Russian Federation [RFMEFI60414X0070]. The funders had no role in study design, data collection and analysis, decision to publish, or preparation of the manuscript.

Copyright: $\odot 2017$ Moiseenko FV et al. This is an open access article distributed under the terms of the Creative Commons Attribution License, which permits unrestricted use, distribution, and reproduction in any medium, provided the original work is properly cited. Data associated with the article are available under the terms of the Creative Commons Zero "No rights reserved" data waiver (CC0 1.0 Public domain dedication).

How to cite this article: Moiseenko FV, Volkov N, Bogdanov A et al. Resistance mechanisms to drug therapy in breast cancer and other solid tumors: An opinion [version 1; peer review: 2 approved, 1 approved with reservations] F1000Research 2017, 6:288 https://doi.org/10.12688/f1000research.10992.1

First published: 17 Mar 2017, 6:288 https://doi.org/10.12688/f1000research.10992.1 
Breast cancer is one of the most frequent cancers among solid tumors in women. Drug therapy is an important part of primary treatment for loco-regional breast cancer, and is a cornerstone of treatment in advanced disease ${ }^{1}$. In contrast to the significant efficacy of first line chemotherapy, inevitably in subsequent lines a vast majority of patients develop drug resistance ${ }^{2}$. Currently, knowledge concerning resistance to cytotoxic antineoplastic agents is based primarily and solely on separate mechanisms that underlie tolerance to single agents $\mathrm{s}^{3-10}$. This approach, though it is experimentally verified, is not able to explain the resistance to multiple agents, which is not dependent on the mechanism of drug anticancer cation, and is either present at the beginning of treatment or formed during subsequent lines of therapy in all patients. Consequently, other universal complex mechanisms that allow tumor cells to escape inhibition by antineoplastic agents should exist and be revealed by now.

For localized stages, and particularly for breast cancer, elimination of tumor cells can be achieved by surgical excision or radical radiotherapy. Efficacy of these approaches does not depend on the heterogeneity of the tumor. Theoretically, administration of antineoplastic agents that interact with particular, sometimes not identified, mechanisms of tumor pathogenesis should also cause the death of all tumor cells, which would be equal to a cure. Due to various resistance mechanisms, described in detail below, drug therapy by itself rarely cures cancer, even in the case of such chemosensitive tumors as breast cancer. Malignant cells that survive primary treatment continue to evolve with appearance or overgrowth of a resistant clone population, which leads to progression and inevitably death of the patient. In these circumstances, identification of transforming mechanisms of resistance obtained by tumor cells might help to define optimal character, intensity and/or longevity of primary and consecutive treatment, which might achieve maximal eradication of tumor cells. This eradication by itself should decrease the clonal variability and influence the evolutionary potential of the tumor ${ }^{11}$.

This paradigm is particularly important for hematologic malignancies. All clones are present in the bloodstream and/or bone marrow. Therefore, monitoring of the residual tumor burden has become possible with the introduction of new, highly sensitive molecular diagnostics, including direct sequencing, allele specific RT-PCR and digital PCR. For hematologic malignancies, it is essential to achieve a complete molecular response, which has been correlated with the longest time to disease progression. For example, in chronic myeloid leukemia complete cytogenetic and molecular response during the first three months of treatment is correlated with maximal survival and longest disease free interval ${ }^{12}$.

Unfortunately, in contrast to hematologic malignancies in solid tumors, such as breast cancer, markers fitting the so-called "liquid biopsy" paradigm (i.e. circulating tumor cells and DNA) cannot always be found in biofluids, even in progressing advanced conditions. This peculiarity defines the necessity for the acquisition of histological, or at least cytological, samples from the primary tumor or metastatic site. As a good example, we can mention monitoring activating mutations in the biofluids of patients with non-small cell lung cancer. The identification of driver molecular alterations is currently possible, with a very high sensitivity ${ }^{13,14}$. However, even the most advanced technologies allow the correct identification of mutations in bioliquids in 6-7 out of 10 patients (for example, direct sequencing: 16.7-77.8\%; PCR with enrichment: 4.7-49.3\%; cobas ROCHE: $12.1 \%)^{15,16}$.

Furthermore, even achieving a complete clinical and radiologic response in tumors of a solid nature does not mean elimination of all tumor cells, as has been shown for preoperative treatment of rectal cancer or colorectal cancer metastases ${ }^{17,18}$. The same situation was also shown for perioperative treatment of breast cancer, where even one cell with epithelial markers found in bone marrow determines a significantly worse long-term outcome and risk of disease recurrence ${ }^{19}$.

Despite a large number of identified mechanisms that may underlie resistance to conventional cytotoxic and targeted drugs, none of them can fully explain multidrug resistance, which is inevitably acquired by all patients with advanced breast cancer and other tumors. Among other examples of acquired resistance, one can mention the decrease in the longevity of second line treatment in comparison with first line ${ }^{8}$. This decrease might be caused by the genetic heterogeneity that is a characteristic feature of all malignancies. This conception is illuminated in the GERCOR trial, where patients with inoperable colorectal cancer were randomized to two treatment groups. In group one, patients received FOLFOX as a first line and FOLFIRI as second and vice versa in group two. As a result no difference in overall survival was observed (21.5 versus 20.6 months; $\mathrm{p}=0.99$ ), but what is important is that no difference was observed in the progression free survival of first line ( 8.5 versus 8.0 months; $\mathrm{p}=0.26$ ) or second line (14.2 versus 10.9 months; $p=0.64)$ chemotherapy ${ }^{20}$. Small differences were noticed in progression free survival of second line (4.2 versus 2.5 months, $\mathrm{p}=0.003$ ). Still the duration of the effect derived from first line was much larger than that of second line. This observation might be interpreted in the way that irrespectively of the initial regimen, the tumor mass at progression is composed of a clone with multidrug resistant features. This clone might have appeared during therapy or might have existed in a small proportion prior to the start of treatment. The latter can be illustrated with an example from NSCLC, when the T790M mutation that defines resistance to first generation TKI can be found in primary samples or may appear during TKI therapy ${ }^{14,21}$.

Furthermore, we can speculate that the appearance of a resistant clone or its presence at the initial tumor development might be probabilistic. To illustrate this idea, we can mention the N9741 trial, in which out of 1508 patients with inoperable colorectal cancer, complete radiologic response was seen in 62 patients. During consecutive follow up, 10/62 patients did not have disease progression and might be considered cured of metastatic disease ${ }^{22}$. Thus, in combination with several circumstances, primary clones can be eradicated by primary chemotherapy and thus are not involved in the development of new resistant subclones.

Research aimed to define mechanisms of resistance are usually based on the determination of genotypic and/or phenotypic features that drive resistant clones, and a myriad of methods have been used, 
among them molecular, chemical and physical analysis. However, the most important avenue for resistance research might be the model by which resistance is created. There are two main directions to model the resistance to therapeutic agents: first, in vitro modeling of the interaction between tumor cells and active antineoplastic agent; and second, in vivo experimental systems, such as laboratory animals.

In vitro methods are historically the first type used. Interestingly, these methods were significant for antibiotics therapies, before it became necessary to use them for oncological purposes. Isolation and cultivation of a pathogenic microorganism beyond the host organism is used to define its sensitivity to antimicrobial agents, and describe phenotypes and molecular profiles, which are of essential importance for clinical decisions on treatment and for the development of newer agents.

This approach has been used for research in all malignant tumors. Immortalized cell lines and primary cell cultures have been successfully used to screen hundreds of components for antineoplastic activity and the definition of the mechanism of action of several therapeutic agents ${ }^{23,24}$. Unfortunately, despite numerous programs of investigation into resistance mechanisms in cell lines exposed to various doses and schedules of chemotherapeutic agents, a significant change in the understanding of these mechanisms has not occurred.

Firstly, unlike bacteria and other microorganisms, whose population in one host organism is limited with rarely more than one strain and evolution of resistance to antibiotics take place in several hosting organisms, evolution of malignant tumors is limited to the life of one host organism and is driven by the diversity of clones and genome instability. For this reason, isolation of a cell line or primary cell culture can hardly model the representative heterogeneous tumor cell population as it is inevitably accompanied by tumor cell dedifferentiation and loss of phenotypical heterogeneity. This observation might not limit in vitro drug testing programs, but significantly restricts resistance research potential.

Secondly, tumor cell cultures in vitro are usually deprived of microenvironment communication, which in some situations might be an essential mechanism for resistance generation and maintenance. Thirdly, tumor cell cultures are characterized by homogenous habitat conditions, for example there are no differences in the distance to supply blood vessels, which does not allow for model exposition to different drug concentrations at one time ${ }^{25}$.
Nevertheless, programs conducted on cell cultures allow the determination of several mechanisms that might underlie resistance, or at least compromise the efficacy of various agents. Amidst them, one can mention various mechanisms, inlcuding mediating drug efflux (increased expression of ATP-binding cassette, including P-glycolprotein, multidrug-resistance-associated protein 1 and breast cancer resistance protein ${ }^{3,26,27}$ ), increasing the expression of metabolic enzymes, deactivating cytotoxic drugs (CYP2C9*2), and modulating targets for cytotoxic drugs (increased expression pf beta-III-isoform of tubulin ${ }^{4}$, increased expression of $\mathrm{Tau}^{6}$, decreased expression of Top-II-alpha ${ }^{28,29}$ ). Unfortunately, patterns revealed once are rarely verified in consecutive series with the same conditions but different cell lines. Also, mechanisms identified as the primary mechanism in one series appear to be secondary or even nonsignificant in the others $^{27}$. As an example, we can mention an experiment where the efficacy of paclitaxel was compromised by different resistance mechanisms on one cell line exposed to different schedules of the drug ${ }^{29,30}$. Interestingly this appeared to be true also for the targeted agents, such as NSCLC with EGFR activating mutations that depended on the exposition dose of gefitinib developed either T790M or MET mediated resistance.

In conclusion, we suggest that the mechanism of multidrug resistance that inevitably develops during drug therapy of breast cancer, and other tumors of solid origin, have not yet been revealed. In our opinion the mechanism of resistance is most likely not directly related to drug metabolism or its target in the tumor cell.

\section{Author contributions}

All authors conceptualized the study, collected data and performed analysis. All authors were involved in the writing and revision of the draft manuscript and have agreed to the final content.

\section{Competing interests}

No competing interests were disclosed.

\section{Grant information}

This work was supported by The Ministry of Education and Science of Russian Federation [RFMEFI60414X0070].

I confirm that the funders had no role in study design, data collection and analysis, decision to publish, or preparation of the manuscript.
1. Chabner BA, Roberts TG Jr: Timeline: Chemotherapy and the war on cancer. Nat Rev Cancer. 2005; 5(1): 65-72. PubMed Abstract | Publisher Full Text

2. Gonzalez-Angulo AM, Morales-Vasquez F, Hortobagyi GN: Overview of resistance to systemic therapy in patients with breast cancer. Adv Exp Med Biol. 2007; 608: $1-22$

PubMed Abstract | Publisher Full Text
3. Chen YN, Mickley LA, Schwartz AM, et al:: Characterization of adriamycinresistant human breast cancer cells which display overexpression of a novel resistance-related membrane protein. J Biol Chem. 1990; 265(17): 10073-10080. PubMed Abstract

4. Murray S, Briasoulis E, Linardou $\mathrm{H}$, et al.: Taxane resistance in breast cancer: mechanisms, predictive biomarkers and circumvention strategies. Cancer Treat 
Rev. 2012; 38(7): 890-903.

PubMed Abstract | Publisher Full Text

5. Tommasi S, Mangia A, Lacalamita R, et al: Cytoskeleton and paclitaxe sensitivity in breast cancer: the role of beta-tubulins. Int J Cancer. 2007; 120(10): 2078-2085.

PubMed Abstract | Publisher Full Text

6. Wagner P, Wang B, Clark E, et al:: Microtubule Associated Protein (MAP)-Tau: a novel mediator of paclitaxel sensitivity in vitro and in vivo. Cell Cycle. 2005; 4(9): 1149-1152.

PubMed Abstract | Publisher Full Text

7. Li WJ, Zhong SL, Wu YJ, et al:: Systematic expression analysis of genes related to multidrug-resistance in isogenic docetaxel- and adriamycin-resistant breast cancer cell lines. Mol Biol Rep. 2013; 40(11): 6143-6150.

PubMed Abstract | Publisher Full Text

8. Sharifi S, Barar J, Hejazi MS, et al:: Roles of the Bcl-2/Bax ratio, caspase-8 and 9 in resistance of breast cancer cells to paclitaxel. Asian Pac J Cancer Prev. 2014; 15(20): 8617-8622.

PubMed Abstract | Publisher Full Text

9. Baselga J, Zambetti M, Llombart-Cussac A, et al:: Phase II genomics study of ixabepilone as neoadjuvant treatment for breast cancer. J Clin Oncol. 2009; 27(4): 526-534.

PubMed Abstract | Publisher Full Text

10. Kutuk O, Letai A: Alteration of the mitochondrial apoptotic pathway is key to acquired paclitaxel resistance and can be reversed by ABT-737. Cancer Res. 2008; 68(19): 7985-7994.

PubMed Abstract | Publisher Full Text | Free Full Text

11. Gillies RJ, Verduzco D, Gatenby RA: Evolutionary dynamics of carcinogenesis and why targeted therapy does not work. Nat Rev Cancer. 2012; 12(7): 487-493. PubMed Abstract | Publisher Full Text | Free Full Text

12. Druker BJ, Guilhot F, O'Brien SG, et al.: Five-year follow-up of patients receiving imatinib for chronic myeloid leukemia. N Engl J Med. 2006; 355(23): 2408-2417. PubMed Abstract | Publisher Full Text

13. Chen K, Zhou F, Shen W, et al.: Novel Mutations on EGFR Leu792 Potentially Correlate to Acquired Resistance to Osimertinib in Advanced NSCLC. J Thorac Oncol. 2017; pii: S1556-0864(17)30010-2. PubMed Abstract | Publisher Full Text

14. Thress KS, Paweletz CP, Felip E, et al:: Acquired EGFR C797S mutation mediates resistance to AZD9291 in non-small cell lung cancer harboring EGFR T790M. Nat Med. 2015; 21(6): 560-562. PubMed Abstract | Publisher Full Text | Free Full Text

15. Luo J, Shen L, Zheng D: Diagnostic value of circulating free DNA for the detection of EGFR mutation status in NSCLC: a systematic review and metaanalysis. Sci Rep. 2014; 4: 6269. PubMed Abstract | Publisher Full Text

16. Levy B, Hu Zl, Cordova KN, et al: Clinical Utility of Liquid Diagnostic Platforms in Non-Small Cell Lung Cancer. Oncologist. 2016; 21(9): 1121-1130. PubMed Abstract | Publisher Full Text | Free Full Text

17. Nair RM, Siegel EM, Chen DT, et al.: Long-term results of transanal excision after neoadjuvant chemoradiation for T2 and T3 adenocarcinomas of the rectum. J Gastrointest Surg. 2008; 12(10): 1797-805; discussion 1805-6. PubMed Abstract | Publisher Full Text
18. Egger ME, Cannon RM, Metzger TL, et al:: Assessment of chemotherapy response in colorectal liver metastases in patients undergoing hepatic resection and the correlation to pathologic residual viable tumor. $J$ Am Coll Surg. 2013; 216(4): 845-56; discussion 856-7.

PubMed Abstract | Publisher Full Text

19. Braun S, Kentenich C, Janni W, et al:: Lack of effect of adjuvant chemotherapy on the elimination of single dormant tumor cells in bone marrow of high-risk breast cancer patients. J Clin Oncol. 2000; 18(1): 80-86. PubMed Abstract | Publisher Full Text

20. Tournigand $\mathrm{C}$, Andre T, Achille $\mathrm{E}$, et al:: FOLFIRI followed by FOLFOX6 or the reverse sequence in advanced colorectal cancer: a randomized GERCOR study. J Clin Oncol. 2004; 22(2): 229-237.

PubMed Abstract | Publisher Full Text

21. Kosaka $\mathrm{T}$, Yatabe $\mathrm{Y}$, Endoh $\mathrm{H}$, et al:: Analysis of epidermal growth factor receptor gene mutation in patients with non-small cell lung cancer and acquired resistance to gefitinib. Clin Cancer Res. 2006; 12(19): 5764-5769. PubMed Abstract | Publisher Full Text

22. Goldberg RM: N9741: a phase III study comparing irinotecan to oxaliplatincontaining regimens in advanced colorectal cancer. Clin Colorectal Cancer. 2002; 2(2): 81

PubMed Abstract | Publisher Full Text

23. Wilding JL, Bodmer WF: Cancer cell lines for drug discovery and development. Cancer Res. 2014; 74(9): 2377-2384. PubMed Abstract | Publisher Full Tex

24. Cree IA, Glaysher S, Harvey AL: Efficacy of anti-cancer agents in cell lines versus human primary tumour tissue. Curr Opin Pharmacol. 2010; 10(4): 375-379. PubMed Abstract | Publisher Full Text

25. Yeung DT, Parker WT, Branford S: Molecular methods in diagnosis and monitoring of haematological malignancies. Pathology. 2011; 43(6): 566-579.

PubMed Abstract | Publisher Full Text

26. Noguchi K, Katayama K, Sugimoto Y: Human ABC transporter ABCG2/BCRP expression in chemoresistance: basic and clinical perspectives for molecular cancer therapeutics. Pharmgenomics Pers Med. 2014; 7: 53-64. PubMed Abstract | Publisher Full Text | Free Full Text

27. Redmond KM, Wilson TR, Johnston PG, et al.: Resistance mechanisms to cancer chemotherapy. Front Biosci. 2008; 13(13): 5138-5154. PubMed Abstract | Publisher Full Text

28. Raguz S, Adams $\mathrm{C}$, Masrour $\mathrm{N}$, et al.: Loss of $\mathrm{O}^{6}$-methylguanine-DNA methyltransferase confers collateral sensitivity to carmustine in topoisomerase II-mediated doxorubicin resistant triple negative breast cancer cells. Biochem Pharmacol. 2013; 85(2): 186-196. PubMed Abstract | Publisher Full Text

29. Li WJ, Zhong SL, Wu YJ, et al.: Systematic expression analysis of genes related to multidrug-resistance in isogenic docetaxel- and adriamycin-resistant breast cancer cell lines. Mol Biol Rep. 2013; 40(11): 6143-6150. PubMed Abstract | Publisher Full Text

30. $\mathrm{Ng} \mathrm{CK}$, Weigelt $\mathrm{B}, \mathrm{A}^{\prime} \mathrm{Hern} \mathrm{R}$, et al:: Predictive performance of microarray gene signatures: impact of tumor heterogeneity and multiple mechanisms of drug resistance. Cancer Res. 2014; 74(11): 2946-2961. PubMed Abstract | Publisher Full Text | Free Full Text 


\section{Open Peer Review}

\section{Current Peer Review Status:}

\section{Version 1}

Reviewer Report 10 July 2017

https://doi.org/10.5256/f1000research.11851.r24106

(C) 2017 Herman-Antosiewicz A. This is an open access peer review report distributed under the terms of the Creative Commons Attribution License, which permits unrestricted use, distribution, and reproduction in any medium, provided the original work is properly cited.

\section{Anna Herman-Antosiewicz}

Department of Medical Biology and Genetics, University of Gdańsk, Gdańsk, Poland

Recurrence and multidrug resistance is a major problem in cancer therapy. The authors discuss this important issue and it becomes clear that the first line treatment should be designed in such a way to eradicate all cancer cells, having in mind that at a time of diagnosis they are heterogenous and some of them are already drug resistant (in an otherwise naïve population).

The authors highlight that numerous mechanisms responsible for resistance to therapy have been identified, mainly thanks to in vitro experiments. They also mention disadvantages of such an approach, including lack of original microenvironment which is unstable in its nature. That's why, probably, none of the known mechanisms fully explain multidrug resistance. However, there is experimental evidence that microenvironment conditions during tumor development $\mathrm{pH}$ or oxygen level changes) might drive genetic and phenotypic changes in cancer cells leading to their more aggressive character and multidrug resistance (for example, Taylor et al. (2015) ${ }^{1}$ or Verduzco et al. (2015) ${ }^{2}$. In my opinion, this aspect should be mentioned by the authors, as the tumor microenvironment might be a good target for an adjuvant treatment, also to prevent the recurrence of the more aggressive tumors.

Minor comments:

GERCOR trial results are incorrectly presented

Misspelling: $p 1$, line 11- should be: action (not cation)

\section{References}

1. Taylor S, Spugnini EP, Assaraf YG, Azzarito T, et al.: Microenvironment acidity as a major determinant of tumor chemoresistance: Proton pump inhibitors (PPIs) as a novel therapeutic approach.Drug Resist Updat. 2015; 23: 69-78 PubMed Abstract | Publisher Full Text

2. Verduzco D, Lloyd M, Xu L, Ibrahim-Hashim A, et al.: Intermittent hypoxia selects for genotypes and phenotypes that increase survival, invasion, and therapy resistance.PLoS One. 2015; 10 (3): e0120958 PubMed Abstract | Publisher Full Text 
Is the topic of the opinion article discussed accurately in the context of the current literature?

Yes

Are all factual statements correct and adequately supported by citations? Partly

Are arguments sufficiently supported by evidence from the published literature? Partly

Are the conclusions drawn balanced and justified on the basis of the presented arguments? Yes

Competing Interests: No competing interests were disclosed.

I confirm that I have read this submission and believe that I have an appropriate level of expertise to confirm that it is of an acceptable scientific standard.

Reviewer Report 27 June 2017

https://doi.org/10.5256/f1000research.11851.r23679

(C) 2017 Saw P. This is an open access peer review report distributed under the terms of the Creative Commons Attribution License, which permits unrestricted use, distribution, and reproduction in any medium, provided the original work is properly cited.

Phei Er Saw

Post-Doctoral Fellow, Department of Anesthesiology, Harvard Medical School, Boston, MA, USA

The article is supposed to focus on the possible resistance mechanism to drug therapy in breast cancer. Yet, most literature review and examples cited are based on colorectal cancer, and none of the breast cancer trials are mentioned. The article is not articulated in a way to guide the readers point-to-point and rather scarce in consummating all the points systematically.

The author also did not clearly point out what are the current problems and resistance mechanism in breast cancer, what are the current approaches to overcome these problems and what is the possible outlook in overcoming drug resistance in breast cancer.

Is the topic of the opinion article discussed accurately in the context of the current literature?

Partly

Are all factual statements correct and adequately supported by citations? Yes 
Are arguments sufficiently supported by evidence from the published literature? Yes

Are the conclusions drawn balanced and justified on the basis of the presented arguments? Partly

Competing Interests: No competing interests were disclosed.

I confirm that I have read this submission and believe that I have an appropriate level of expertise to confirm that it is of an acceptable scientific standard, however I have significant reservations, as outlined above.

Reviewer Report 24 March 2017

https://doi.org/10.5256/f1000research.11851.r21105

(C) 2017 Tryakin A. This is an open access peer review report distributed under the terms of the Creative Commons Attribution License, which permits unrestricted use, distribution, and reproduction in any medium, provided the original work is properly cited.

\section{Alexey Tryakin}

Department of Clinical Pharmacology and Chemotherapy, N.N. Blokhin Russian Cancer Research Center, Moscow, Russian Federation

In this well-written mini-review the authors discuss important questions concerning mechanisms of tumor resistance which result to low concordance between in vitro and in vivo models.

Minor comment: Authors have made a mistake by citing GERGOR trial data (FOLFOX vs. FOLFIRI). They write: "As a result no difference in overall survival was observed (21.5 versus 20.6 months; $p$ $=0.99$ ), but what is important is that no difference was observed in the progression free survival of first line ( 8.5 versus 8.0 months; $p=0.26$ ) or second line (14.2 versus 10.9 months; $\boldsymbol{p}=\mathbf{0 . 6 4}$ ) chemotherapy ${ }^{20}$. Small differences were noticed in progression free survival of second line (4.2 versus 2.5 months, $p=0.003)$. "

PFS in second line was 4.2 vs. 2.5 months. However 14.2 vs 10.9 months was a second PFS (from the days 1 of 1-st line to the progression on 2-nd line). I suggest to omit data which I underlined.

Is the topic of the opinion article discussed accurately in the context of the current literature?

Partly

Are all factual statements correct and adequately supported by citations? Partly

Are arguments sufficiently supported by evidence from the published literature? 


\section{Partly}

Are the conclusions drawn balanced and justified on the basis of the presented arguments? Partly

Competing Interests: No competing interests were disclosed.

I confirm that I have read this submission and believe that I have an appropriate level of expertise to confirm that it is of an acceptable scientific standard.

The benefits of publishing with F1000Research:

- Your article is published within days, with no editorial bias

- You can publish traditional articles, null/negative results, case reports, data notes and more

- The peer review process is transparent and collaborative

- Your article is indexed in PubMed after passing peer review

- Dedicated customer support at every stage

For pre-submission enquiries, contact research@f1000.com 